\title{
Pemanfaatan E-Commerce Sebagai Solusi Inovasi Dalam Menjaga Sustainability Bisnis
}

\author{
Alexander Wirapraja \\ Program Studi Manajemen \\ STIE IBMT \\ alex@ibmt.ac.id
}

\author{
Handy Aribowo \\ Program Studi Manajemen \\ STIE IBMT \\ handy@ibmt.ac.id
}

\begin{abstract}
Abstrak - Proses peralihan bisnis dari konvensional menjadi digital menyebabkan perusahaan perlu memikirkan langkah strategis untuk membuat bagaimana proses bisnis yang ada di dalamya menjadi keberlanjutan. Salah satu caranya adalah memanfaatkan perkembangan teknologi pada bidang pemasaran yang mengubah cara pengerjaan suatu pekerjaan dari cara konvensional mengarah kepada teknologi digital dengan memanfaatkan e-commerce. Pertumbuhan pengguna internet yang semakin pesat pada tahun 2017 sebesar 143,26 juta juga menjadi faktor utama pergeseran perilaku belanja masyarakat menjadi lebih dinamis, dimana konsumen menginginkan distribusi produk yang lebih cepat dengan hasil yang lebih baik. Metodologi yang digunakan dalam penelitian ini adalah tinjauan konseptual, yaitu metode yang dilakukan dengan mengumpulkan data dan informasi yang berkaitan potensi pasar, perubahan perilaku konsumen dan bagaimana memanfaatkan teknologi e-commerce sebagai solusi alternatif dalam melakukan inovasi pada strategi pemasaran dengan tujuan untuk menjaring potensi pasar yang lebih besar.
\end{abstract}

Kata Kunci: E-Commerce, Inovasi Bisnis, Internet, Sustainability.

\section{PENDAHULUAN}

Proses bisnis yang berkelanjutan adalah keinginan setiap perusahaan. Namun hingga saat ini proses bisnis masih didominasi oleh pola pemikiran jangka pendek dimana hanya berfokus pada sebatas pendapatan (revenue) saja. Apalagi di zaman modern saat ini dimana teknologinya berubah dengan sangat cepat, banyak praktisi dan pelaku bisnis yang masih mengabaikan pola pikir jangka panjang. Dengan kata lain adalah belum adanya pemikiran dari pelaku bisnis untuk menjaga aspek keberlanjutan pada perusahaannya. Hal ini dapat terjadi dikarenakan pemikiran mengenai peluang dan tantangan di masa depan bersifat ketidakpastian.

Pola pemikiran semacam ini harus diubah mengingat tingkat persaingan bisnis dan faktor kompetisi yang semakin tinggi yang pada saat ini dinamakan dengan era disruption. Maka dari itu perusahaan diharapkan perlu untuk melakukan inovasi terhadap produk dan lini operasional bisnisnya demi menjamin keberlanjutan dari proses bisnis yang akan mereka hadapi.

Melihat adanya potensi akan risiko yang akan dihadapi oleh perusahaan bisnis, maka penerapan teknologi $e$ commerce merupakan salah satu aspek yang penting yang dapat dikembangkan dalam rangka menunjang keberhasilan siklus hidup produk dari proses produksi hingga sampai bagaimana produk tersebut dipasarkan. Sebagai contoh untuk mempercepat dan meningkatkan penjualan maka perlu melihat perkembangan teknologi informasi yang sangat pesat seperti survei yang dilakukan oleh Asosiasi Pengguna Jasa Internet Indonesia tahun 2017 [1]. Pada gambar 1 menunjukkan jumlah pengguna internet Indonesia yang berkembang dan mengalami kenaikan setiap tahunnya. Berdasarkan fenomena tersebut, layanan secara on-line dengan efektif dan efisien menjadi salah satu kunci dalam memenangkan era persaingan bisnis di masa depan.

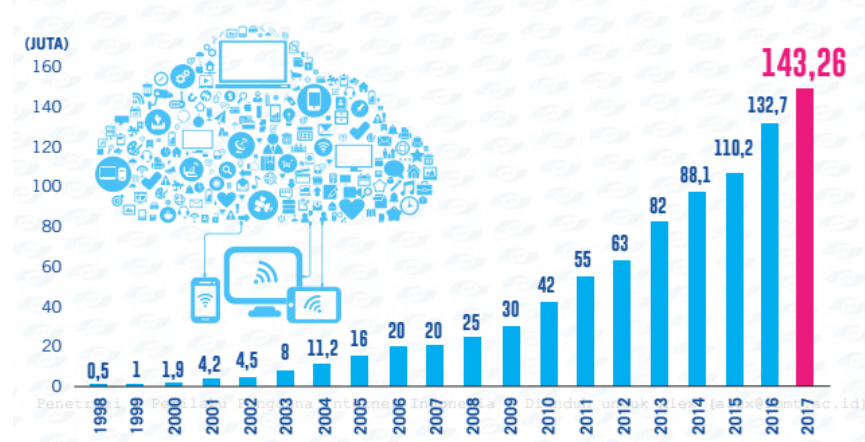

Gambar 1. Pertumbuhan Pengguna Internet Indonesia [1].

Bila selama ini, masih ada perusahaan yang melakukan sistem penjualan secara tertulis dan manual, maka tidak jarang akan rentan terjadi banyaknya kesalahan. Maka diharapkan dengan adanya layanan jasa berupa e-commerce yang dapat secara cepat dinikmati oleh pelanggan maupun perusahaan sendiri, maka segala layanan yang diinginkan oleh para pelanggan dapat segera ditindaklanjuti dengan secepat mungkin. Dengan demikian perusahaan tersebut akan mampu memberikan pelayanan yang terbaik dan tercepat bagi para pelanggan dan tentunya akan membuat proses bisnis yang ada pada perusahaan akan berjalan dengan stabil sehingga diharapkan dapat berdampak 
signifikan bagi keberlangsungan (sustainability) perusahaan itu sendiri.

Pada tahun 2013 perusahaan konsultan manajemen kelas dunia McKinsey dalam laporan Mckinsey Consumer Insight memprediksi bahwa 5 tahun ke depan tren belanja konsumen via e-commerce di Indonesia akan meningkat 10 kali lipat dari 3\% menjadi 30\% [2].

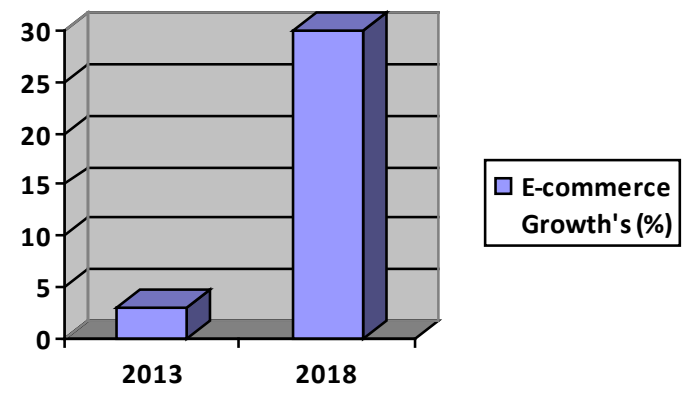

Gambar 2. Prediksi Pertumbuhan E-Commerce 20132018 [2].

Di Indonesia sendiri perkembangan e-commerce pada tahun 2017 sebenarnya telah menunjukkan perkembangan yang signifikan selaras dengan semakin bertumbuhnya jumlah pengguna internet Indonesia. Beberapa hal inilah yang menjadikan e-commerce Indonesia mempunyai potensi untuk menarik minat investor seperti Alibaba untuk menanamkan modal investasi pada dua e-commerce yang paling banyak dicari di Indonesia yaitu Lazada dan Tokopedia seperti pada data gambar 3 [3].

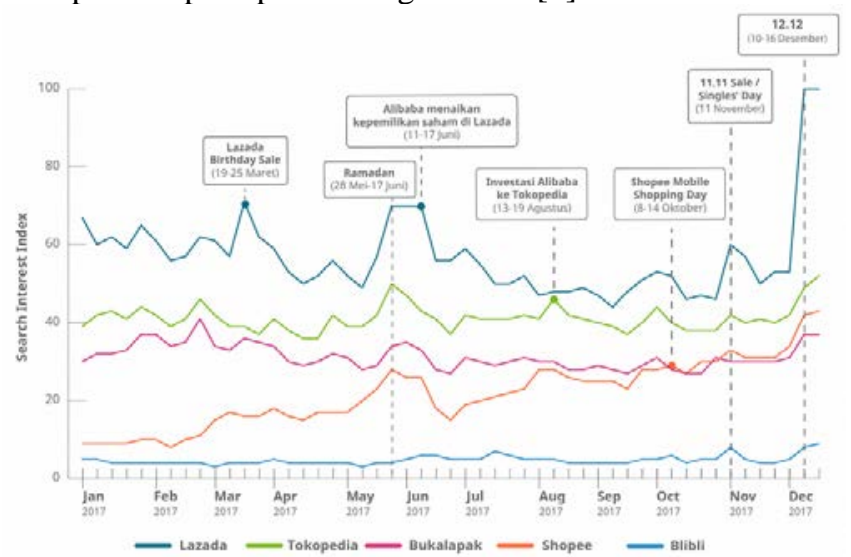

Gambar 3. E-Commerce yang Populer di Indonesia Tahun 2017 [3].

Faktor pertumbuhan e-commerce ini salah satunya dilatar belakangi oleh penanaman investasi oleh Alibaba kepada Lazada dan Tokopedia. Secara khusus Lazada dari 51\% menjadi 83\%, dan dilanjutkan kemudian mereka mengalirkan dana kepada Tokopedia sebesar 1,1 miliar Dolar. Faktor lainnya adalah adanya kampanye secara besar besaran yang dinamakan Harbolnas (Hari Belanja Online Nasional) yang dilakukan secara periodik.

\section{TINJAUAN PUSTAKA}

\section{A. E-Commerce}

Pengertian e-commerce adalah sistem pemasaran secara atau dengan penggunaan akses internet, situs web, dan aplikasi mobile dan browser yang berjalan pada perangkat mobile dan digunakan untuk transaksi bisnis, secara formal dapat juga berarti adanya transaksi komersial antar organisasi dan antar individu [4]. Pendapat lain menyatakan bahwa e-commerce adalah penggunaan internet dan komputer dengan browser web untuk membeli dan menjual produk, sebagian besar e-commerce terjadi antarbisnis, dan bukan antara bisnis dan konsumen [5].

Cakupan e-commerce sendiri cukup luas yang umumnya mencakup layanan distribusi, penjualan, pembelian, marketing, layanan purna jual dan service dari sebuah produk yang secara keseluruhan dilakukan dalam sebuah sistem elektronika seperti internet atau bentuk jaringan komputer yang lain. E-commerce adalah perpaduan antara jasa dan barang serta kegiatan transaksi yang dilakukan terkait melalui internet yang diharapkan dapat menjadi penggerak untuk memperbaiki perekonomian domestik melalui liberalisasi jasa domestik dan mempercepat integrasi dengan kegiatan produksi global. Seperti pada Gambar 4 dimana kegiatan e-commerce dan e-business adalah proses kegiatan menghubungkan antara supplier kepada perusahaan atau hubungan perusahaan kepada konsumen dengan memanfaatkan proses bisnis yang dilakukan melalui infrastruktur teknologi.

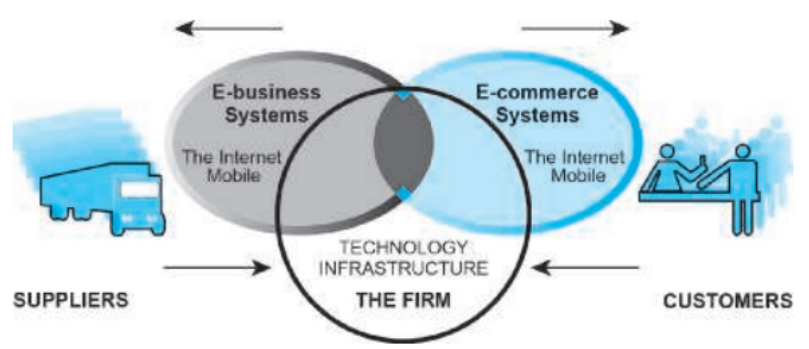

Gambar 4. Perbedaan E-Commerce dan E-Business [4].

Secara umum tipe $e$-commerce dapat dibedakan menjadi beberapa bagian yaitu [4] :

1. B2C (Business to Customer)

Dapat diartikan perusahaan menjual produk perusahannya kepada para pelaku ritel atau langsung kepada pelanggan. Contohnya Amazon menjual produk dengan menawarkan gimmick dan merchandise kepada calon pelangganya.

2. B2B (Business to Business)

Perusahaan menjual bahan mentah kepada perusahaan lain untuk diolah menjadi bahan jadi. Contohnya adalah perusahaan Go2Paper yang menjadi pihak ketiga dalam memasarkan produknya ke perusahaan pengolahan kertas.

3. C2C (Customer to Customer)

Penjualan yang dilakukan oleh konsumen sendiri sebagai mitra bisnis kepada konsumen lainnya. Contohnya adalah penggunaan aplikasi Airbnb dan Uber yang memfasilitasi 
penyedia jasa dalam hal ini konsumen yang menjadi anggota pada aplikasi ini untuk memasarkan produknya langsung kepada konsumen.

4. M-Commerce (Mobile Commerce)

Penggunaan aplikasi mobile seperti laptop dan ponsel untuk memfasilitasi transaksi komersial.

5. Social E-Commerce

Contohnya adalah Facebook yang mempunyai fungsi ganda sebagai situs jejaring sosial dan penyedia layanan E-Commerce.

6. Local E-Commerce

Contohnya adalah layanan Groupon yang menyediakan kupon diskon dari jaringan bisnis lokal yang dapat digunakan oleh pelanggan kapanpun dibutuhkan.

Pada beberapa kasus sering ditemukan permasalahan yang dialami konsumen pada saat menggunakan jasa $e$ commerce. Salah satunya adalah konsumen tidak dapat menyentuh secara langsung produk yang diinginkannya sehingga kadangkala barang yang ditampilkan pada tampilan antarmuka sering berbeda dengan kondisi barang yang diterima secara nyata. Selain itu faktor waktu dan kondisi pengiriman juga menjadi faktor yang sangat penting, terutama perbedaan lokasi misalnya pengantaran dalam kota, antar pulau, dan provinsi, serta kondisi barang tersebut dari pengiriman hingga sampai kepada konsumen.

Solusi yang telah tersedia adalah sudah banyak tersedianya kurir pengantaran instan untuk pengantaran di dalam kota. Selain itu peran pihak ekspedisi juga menyediakan fasilitas berupa penyediaan kemasan dan terkadang juga menyediakan garansi pengiriman barang elektronik dan pecah belah.

\section{B. Internet of Things (IoT)}

Pengertian internet yaitu merupakan hubungan antar berbagai jenis komputer dan jaringan di dunia yang berbeda sistem operasi maupun aplikasinya, dimana hubungan tersebut memanfaatkan kemajuan komunikasi (telepon dan satelit), yang menggunakan protokol standar dalam berkomunikasi yaitu protokol TCP/IP (Transmission Control Protocol/Internet Protocol) [6].

Sedangkan pengertian lain Internet of Things adalah sebuah konsep yang bertujuan untuk memperluas manfaat dari konektivitas internet yang tersambung secara terusmenerus. Adapun kemampuan seperti berbagi data, remote control, dan sebagainya, termasuk juga pada benda di dunia nyata. Contohnya bahan pangan, elektronik, koleksi, peralatan apa saja, termasuk benda hidup yang semuanya tersambung ke jaringan lokal dan global melalui sensor yang tertanam dan selalu aktif [7].

Internet of Things menurut merupakan sebuah gagasan bahwa objek yang terhubung ke internet dapat menyebabkan pengguna dapat berinteraksi dengan perangkat, aplikasi, atau layanan lain. Dengan kata lain peralatan sehari - hari yang tertanam dengan perangkat keras dapat mampu merasakan, memproses, dan mentransmisikan data. Objek-objek inilah yang kemudian dapat terhubung ke jaringan dan saling berbagi data dengan aplikasi, layanan, atau perangkat elektronik lainnya [8].
Pengelolaan infrastruktur yang berbasiskan internet ini juga diharapkan dapat menciptakan peluang bisnis baru dimana era digital saat ini terdapat potensi banyaknya peluang startup bisnis yang berbasiskan kreativitas sebagai solusi dalam menciptakan lapangan pekerjaan yang baru.

\section{Sustainability}

Business sustainability dapat diartikan sebagai total upaya perusahaan untuk mengurangi dampak pada kehidupan bumi dan ekosistem [9]. Sedangkan corporate sustainability dapat diartikan sebagai kegiatan mengadopsi strategi bisnis dan kegiatan yang memenuhi kebutuhan perusahaan dan stakeholder, sekaligus melindungi, mempertahankan dan meningkatkan sumber daya manusia dan alam yang akan dibutuhkan dimasa yang akan datang [10].

Maka dari itu dapat disimpulkan bahwa sebuah perusahaan perlu memikirkan keberlanjutan proses bisnisnya dengan mempertimbangkan dan menyelaraskan pemanfaatan dari aspek sumber daya yang tersedia, baik sumber daya fisik, material, maupun sumber daya manusia, dan tentunya didukung dengan pemanfaatan teknologi yang efektif dan efisien.

Implementasi business sustainability yang diterapkan oleh perusahaan bertujuan agar perusahaan menjadi selalu peka terhadap suatu perubahan di dalam menyusun suatu rangkaian strategi. Harapannya strategi yang ditetapkan oleh perusahaan mampu melewati berbagai kendala dan tantangan yang akan dihadapi ke depannya.

\section{Manajemen Inovasi}

Arti kata inovasi menurut kamus besar bahasa Indonesia adalah pemasukan atau pengenalan mengenai hal yang baru, dapat juga berupa penemuan baru yang berbeda dari yang sudah ada atau yang sudah dikenal sebelumnya (gagasan, metode, atau alat) [11]. Sedangkan pengertian inovasi adalah keberhasilan secara sosial dan ekonomi karena diperkanalkannya cara baru atau kombinasi baru dan cara lama dalam mengubah input menjadi output sedemikian rupa sehingga dihasilkan perubahan besar dalam perbandingan antara nilai manfaat dan harga menurut persepsi konsumen dan/atau pengguna [12].

Pengertian inovasi adalah suatu ide, gagasan, praktek atau objek/benda yang disadari dan diterima sebagai suatu hal yang baru oleh seseorang atau kelompok untuk diadopsi [13]. Sedangkan inovasi produk adalah gabungan dari berbagai macam proses yang saling mempengaruhi antara yang satu dengan yang lain. Pengertian ini dapat diartikan pula bahwa inovasi bukan merupakan konsep, ide baru, atau penemuan baru dan bukan pula merupakan suatu perkembangan dari suatu pasar yang baru saja, namun merupakan gambaran dari semua proses yang ada tersebut [14].

Inovasi sendiri memiliki empat ciri utama yaitu memiliki kekhasan atau keunikan yang bisa dirupakan dalam bentuk ide, gagasan, sistem atau tahapan, memiliki sifat kebaharuan, dilaksanakan melalui program yang terencana, dan harus mempunyai tujuan akhir yang diinginkan. 


\section{METODOLOGI PENELITIAN}

Berdasarkan pada latar belakang tersebut, penulis mempunyai tujuan untuk mendalami konsep pemanfaatan $e$ commerce sebagai salah satu solusi inovasi dalam menjaga sustainability bisnis. Penelitian dilakukan melalui pendalaman teoritis dan konseptual melalui pengumpulan data dan informasi yang berkaitan dengan e-commerce dan manajemen inovasi melalui data-data pendukung yang bersumber dari jurnal penelitian baik nasional maupun internasional, buku-buku penunjang, surat kabar, dan majalah dan artikel ilmiah pendukung lainnya. Kajian konseptual berupa studi literatur memiliki beberapa tujuan yaitu menginformasikan kepada pembaca hasil-hasil penelitian lain atau penelitian terdahulu yang mempunyai kaitan erat dengan penelitian yang dilakukan saat itu, dengan cara menghubungkan penelitian dengan literatur-literatur yang ada, dan mengisi celah-celah dalam penelitianpenelitian sebelumnya. Kajian ini akan berisi ulasan, rangkuman, dan pemikiran penulis tentang beberapa sumber pustaka (artikel, buku, slide, informasi dari internet, dan lain lain) tentang topik yang dibahas [15].

Metode kajian literatur/kajian pustaka mempunyai sifat yaitu membatasi kegiatannya hanya pada bahan-bahan koleksi perpustakaan saja tanpa memerlukan riset lapangan [16]. Hal ini memberikan kesimpulan bahwa kajian literatur adalah sebuah produk tulisan yang mengupas sebuah topik atau hasil dari penelitian yang telah dipublikasikan, tanpa ada gambaran metodologi ilmiah [17].

\section{HASIL DAN PEMBAHASAN}

Pergeseran pola penjualan pasar modern dan tingkat perilaku pembelian konsumen Indonesia dari pola transaksi secara konvensional menjadi pola transaksi digital secara tidak langsung menyebabkan penggunaan internet yang semakin tidak terbendung dan pergeseran perilaku masyarakat Indonesia yang cenderung menggunakan aplikasi mobile dalam melakukan transaksi hal tersebut.

Berdasarkan data yang dirilis dari Asosiasi Penyedia Jasa Internet Indonesia (APJII) pada tahun 2017 yang menyebutkan bahwa sebanyak 143.26 juta penduduk atau $44.16 \%$ senang menggunakan perangkat mobile dalam melakukan akses terhadap internet dan $0.65 \%$ menggunakan komputer/laptop dalam melakukan akses internet dan sebesar $39.29 \%$ adalah pengguna yang menggunakan kedua perangkat tersebut seperti terlihat pada Gambar 5.

Dari total data ini diketahui pula berdasarkan riset yang dilakukan oleh eMarketer tahun 2017 yang dikutip oleh Sindoweekly, para pengguna melakukan akses terhadap situs penyedia penjualan elektronik terbanyak pada tiga jenis produk seperti pakaian jadi sebesar $45.8 \%$, aksesoris pakaian $10.9 \%$, sepatu $6.7 \%$, data pada Tabel 1 . Hasil riset dari total porsi barang yang dijual menggunakan e-commerce, di luar dari tabel tersebut terdapat empat sektor bisnis yang terus bergerak kearah transaksi daring yaitu sektor perbankan, asuransi, ritel, dan transportasi.

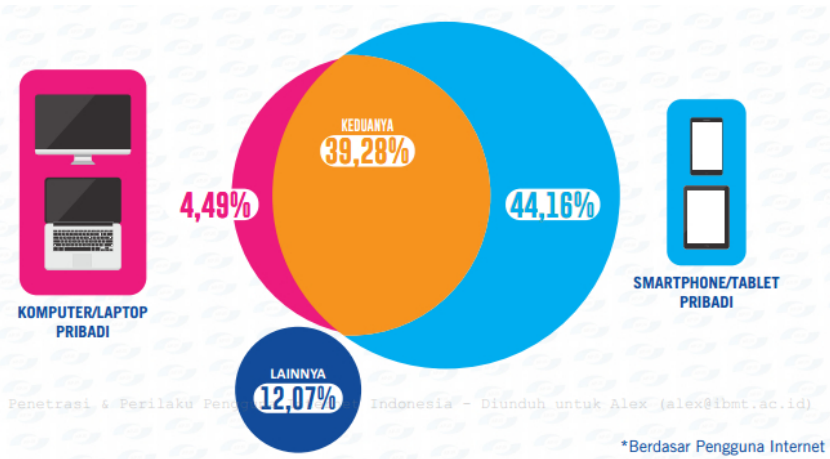

Gambar 5. Perangkat yang Dipakai Mengakses Internet [1].

Tabel 1. Barang yang Diakses Menggunakan E-Commerce.

\begin{tabular}{lr}
\hline Jenis Barang & Persentase \\
\hline Pakaian Jadi & $45.8 \%$ \\
\hline Aksesoris Pakaian & $10.9 \%$ \\
\hline Sepatu & $6.7 \%$ \\
\hline Tiket & $4.7 \%$ \\
\hline Ponsel & $4.6 \%$ \\
\hline Busana Muslim & $3.5 \%$ \\
\hline Produk Kosmetik & $3.5 \%$ \\
\hline Aksesoris Elektronik & $3.5 \%$ \\
\hline Lain-Lain & $17.0 \%$ \\
\hline
\end{tabular}

Berdasarkan data pada Tabel 1, dapat disimpulkan bahwa industri fashion dan gaya hidup menjadi salah satu bidang bisnis yang berpotensi untuk terus mendapatkan keuntungan. Hal ini sebenarnya sudah dibaca oleh peritel besar dengan terlihat dari banyaknya toko online yang sebenarnya juga mempunyai atau berawal dari toko fisik. Contohnya Matahari Mall yang merupakan toko online dari Matahari Department Store dan Mitra Adi Perkasa yang mempunyai Mapemall.com sebagai unit bisnis e-commerce. Penghubung untuk mengembangkan unit-unit bisnis, berupa store, outlet, tenant, maupun toko yang berada dibawah perusahaan tersebut dalam konsep sistem informasi menggunakan gabungan antara toko konvensional dan toko elektronik ini lazim dikenal dengan nama strategi click and brick.

Berdasarkan proyeksi Indef, potensi e-commerce di Indonesia sebenarnya sangat menggiurkan dan diproyeksi akan terus mengalami peningkatan hingga tahun 2021. Sebagai contoh tahun 2017 tercatat nilai transaksi elektronik sebesar US\$6,57 yang berarti ada pertumbuhan ekonomi sebesar $0,712 \%$. Sementara nilai transaksi ini mengalami peningkatan pada tahun 2018 sebanyak US\$ 7,58 dan diproyeksikan pada tahun 2021 akan nilai transaksi elektronik ini akan mengalami peningkatan sebesar US\$11,32.

Perilaku pembeli/konsumen digital juga meningkat seperti pada tahun 2017 tercatat dengan jumlah pembelian sebanyak 26,91 juta orang, dan pada tahun 2018 adalah sebesar 29,35 juta. Dari data ini dapat diproyeksikan pada tahun 2021 akan mengalami peningkatan sebesar 38,34 juta yang berarti secara sectoral, sektor teknologi informasi dan komunikasi akan mengalami pertumbuhan sebesar 18,88\%. 
Data tersebut juga dilengkapi dengan data yang dhimpun dari Kominfo tahun 2018 yang menyebutkan bahwa proyeksi bisnis e-commerce di Indonesia diperkirakan bakal tumbuh 10 kali lipat pada tahun 2020. Nilai perdagangan daring diprediksi akan mencapai USD 130 miliar atau setara dengan Rp 1.800 triliun [18].

Membahas mengenai aspek keberlanjutan dalam dunia bisnis tentunya tidak terlepas dari pola perilaku konsumen yang memiliki kecenderungan untuk memilih melakukan transaksi pembelian barang dan jasa melalui online seperti data yang dilansir oleh eMarketer pada Tabel 2 [4]. Beberapa alasan seorang pelanggan lebih memilih untuk bertransaksi melalui online adalah dikarenakan faktor harga yang murah, berbelanja yang dapat dilakukan dari rumah dan toko yang dapat buka selama 24 jam dalam 7 hari sehingga berbelanja melalui online dapat menjadi alternatif terbaik bagi konsumen di saat seorang konsumen membutuhkan produk atau jasa namun dalam kondisi yang sangat mendesak.

Tabel 2. Alasan Konsumen Memilih Berbelanja Online [4].

\begin{tabular}{lr}
\hline Alasan berbelanja online & Persentase \\
\hline Harga yang murah & $59 \%$ \\
\hline Transaksi dari rumah & $53 \%$ \\
\hline Toko 24/7 & $44 \%$ \\
\hline Produk yang bervariatif & $29 \%$ \\
\hline $\begin{array}{l}\text { Mudah membandingkan } \\
\text { produk satu dengan lainnya }\end{array}$ & $27 \%$ \\
\hline $\begin{array}{l}\text { Produk hanya tersedia secara } \\
\text { online }\end{array}$ & $22 \%$ \\
\hline Review pelanggan secara online & $18 \%$ \\
\hline Informasi produk yang jelas & $7 \%$ \\
\hline Promosi melalui email/text & $7 \%$ \\
\hline Pengaruh social media & $1 \%$ \\
\hline
\end{tabular}

Salah satu tantangan dalam e-commerce adalah kepercayaan/trust dari konsumen. Kepercayaan dan $e$ commece dapat diartikan secara umum sebagai image (gambar) apa yang dilihat dan ditawarkan ketika telah terjadi kesepakatan atau transaksi, dimana produk yang ditawarkan sesuai dengan keinginan dari pelanggan tersebut ketika produk sampai di tangan pelanggan. Salah satu peran penting dalam menjalankan bisnis e-commerce adalah adanya transparansi sistem dan teknologi yang selalu ter-update real time ketika terjadi proses transaksi dengan penjual. Dengan sistem yang transparan dan teknologi yang update real time, maka dapat lebih memperkuat kepercayaan dari pelanggan. Untuk itu salah satu sarana membanguna hubungsn dengan pelanggan dalam menjalankan bisnis e-commerce adalah kejujuran dan keterbukaan dalam rangka meraih kepercayaan dari pihak pembeli.

Salah satu keuntungan dari e-commerce dibandingkan dengan menjual secara konvensional adalah dapat memangkas jalur distribusi menjadi lebih pendek. Dengan terpangkasnya jalur distribusi pada e-commece, maka perusahaan mampu melakukan efisiensi dan mampu meningkatkan produktivitas. Khusus pada Usaha Kecil Menengah (UKM) yang memiliki modal terbatas dapat langsung berhubungan dengan pihak pabrik atau penyedia kebutuhan bahan baku atau dapat secara langsung menjual produknya langsung ke konsumen akhir.

Beberapa fitur yang harus ada dalam penerapan teknologi e-commerce adalah:

1. Dapat diakses dimana-mana (ubiquity) yaitu pelaku bisnis harus berusaha untuk mengubah struktur industri dengan cara menciptakan saluran atau strategi pemasaran baru dan memperluas cakupan pasar secara keseluruhan. Salah satunya dapat dengan menciptakan diversifikasi produk, melakukan efisiensi pada operasional industri dengan menurunkan biaya operasi penjualan perusahaan.

2. Jangkauan luas (global reach) dengan mempersiapkan konten untuk memperluas cakupan pasar sehingga dapat diakses tidak hanya pada satu daerah tertentu namun dapat diakses dimana-mana. Langkah awal dapat melakukan penyesuaian standar menjadi lebih umum (universal standard).

3. Fitur aplikasi yang beragam dan interaktif (richness \& interactive) aplikasi e-commerce tidak hanya sebatas penjualan produk saja tapi juga harus dapat menjawab kebutuhan dari pengguna dan dapat melakukan proses komunikasi yang baik dengan pengguna, dan bila perlu dapat menjangkau layanan purna jual produk yang baik dengan konsumen.

4. Mempunyai kemampuan untuk membentuk komunitas terhadap pengguna produk dan jasa, baik terintegrasi melalui situs atau melalui media sosial (social technologies), langganan berita terbaru, dan promosi melalui email diharapkan dapat menciptakan kesan yang baik terhadap produk dan jasa yang dijual.

5. Tampilan antar muka yang baik (graphic user interface). Tampilan antar muka berupa penataan produk dan logo serta pemilihan warna, dan grafik yang menarik diyakini dapat membuat aplikasi e-commerce tersebut semakin diminati konsumen.

6. Aplikasi harus kompatibel (compatibility) terhadap varian browser yang digunakan atau kompatibel terhadap media akses yang digunakan, misalnya melalui komputer pribadi. laptop atau diakses melalui ponsel pribadi.

E-commerce juga membutuhkan suatu infrastruktur digital serta dikuasai oleh orang yang memahami dengan baik dunia digital. Selain itu di dalam pengembangan $e$ commerce juga dibutuhkan integrasi dengan berbagai unsur seperti penggunaan social media, variasi metode pembayaran contohnya melalui kartu debit, pembayaran lewat kartu kredit, pembayaran dengan sistem e-money dan lembaga lainnya yang menyediakan fasilitas pembayaran. Salah satu yang harus terus dilakukan perusahaan ecommerce dalam mendukung sustainability suatu bisnis adalah terus menerus tanpa henti untuk melakukan inovasi. Inovasi merupakan suatu kunci sukses bisnis dalam mebangun suatu nilai tambah, tanpa melakukan inovasi, maka bisnis yang dijalankan akan stagnan dan tidak bisa tumbuh secara maksimal. Terkait dengan inovasi di Indonesia, berdasarkan laporan dari Cornell University, INSEAD, and WIPO tentang Global Innovation Index tahun 2017, menunjukkan bahwa peringkat Indonesia masih berada 
pada posisi peringkat 87 dari 127 negara. Posisi Indonesia di kawasan Asia Tenggara masih berada dibawah negara Singapura (peringkat 7), Malaysia (peringkat 37), dan Vietnam (peringkat 47), Thailand (peringkat 51), dan Filipina (peringkat 73) [19].

Tabel 3. Peringkat Global Innovation Index (GII) 2017 di Kawasan Negara ASEAN [19].

\begin{tabular}{rlr} 
No. & Negara & Peringkat ASEAN \\
\hline 1 & Singapura & 7 \\
\hline 2 & Malaysia & 37 \\
\hline 3 & Vietnam & 47 \\
\hline 4 & Thailand & 51 \\
\hline 5 & Filipina & 73 \\
\hline 6 & Indonesia & 87 \\
\hline 7 & Kamboja & 101 \\
\hline
\end{tabular}

Berdasarkan gambaran tentang inovasi di Indonesia, maka setiap perusahaan di Indonesia perlu untuk melakukan strategi inovasi dalam rangka menjaga sustainability suatu bisnis dengan cara mengabungkan keseluruhan proses yang ada di dalam sebuah proses bisnis dengan memperhatikan faktor keunikan yang dimiliki, kualitas dan daya tahan produk dan kondisi kemampuan dari pesaing. Organisasi diyakini akan berhasil bila menerapkan langkah-langkah yang mampu bertahan dalam perubahan pasar yang cepat dan dinamis.

Di dalam mengimplementasikan suatu inovasi dalam rangka menjaga keberlanjutan (sustainability) dalam suatu bisnis. Data pada Gambar 6 memberikan suatu toolkit penyusunan strategi inovasi yang dapat digunakan oleh perusahaan. Adapun di dalam template tersebut terdapat aspek yang meliputi empat aspek seperti yang terdapat dalam Balance Score Card (BSC) yaitu perspektif finansial (financial perspective), perspektif konsumen (consumer perspective), perspektif internal (internal perspective), dan perspektif pembelajaran dan pertumbuhan (learning and growth perspective) [20].

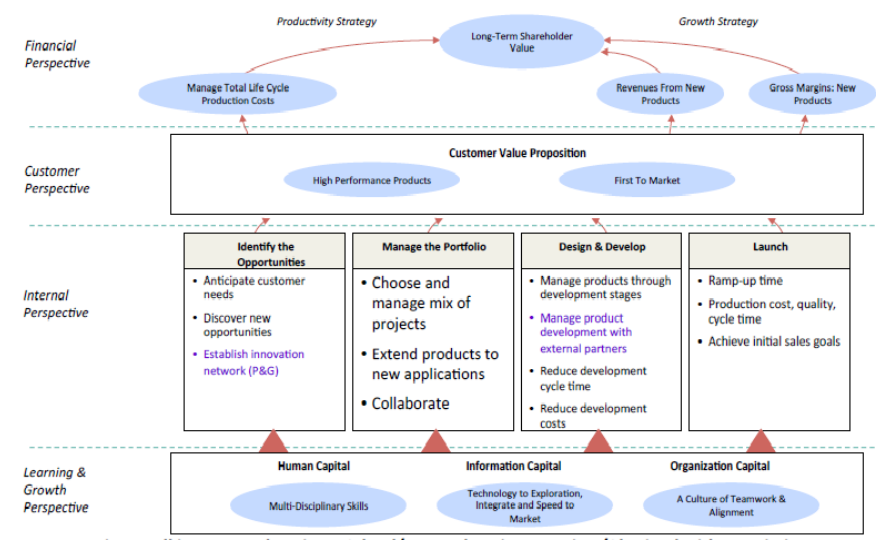

Gambar 6. Innovation Management Strategy Map Template [20].
Secara umum aspek sustainability pada tahun 2005 dicetuskan oleh World Summit on Social Development yang dikutip oleh environmentalscience.org memiliki tiga pilar yaitu: pengembangan ekonomi, pengembangan sosial, dan perlindungan terhadap lingkungan [21].

Pemanfaatan e-commerce pada tiga hal ini sebenarnya dapat dilakukan oleh perusahaan yang menerapkannya salah satunya adalah pada pengembangan pada aspek ekonomi. Dimana e-commerce dapat berperan aktif dalam menjaga tingkat permintaan terhadap barang dan jasa, memangkas biaya promosi, melebarkan pasar pada tingkatan pasar yang baru hingga dapat memangkas jalur distribusi. Tujuan akhir yang diharapkan adalah adanya peningkatan terhadap revenue dari organisasi tersebut.

Pada aspek pengembangan sosial dengan memanfaatkan e-commerce maka perusahaan dapat berkontribusi lebih dengan lebih mendekatkan diri kepada konsumennya melalui layanan pelanggan yang tersedia selama 24 jam sehingga kepuasan pelanggan dapat tercapai dan secara otomatis meningkatkan citra perusahaan tersebut. Hasil akhir yang diharapkan adalah tentunya semakin banyak pelanggan yang melakukan transaksi pada situs e-commerce tersebut.

Pada aspek perlindungan kepada konsumen, peran $e$ commerce lebih banyak dilakukan secara elektronik sehingga dapat mengurangi sampah operasional seperti penggunaan kertas, bahan bakar yang tidak perlu. Dengan demikian tingkat pengeluaran dalam lingkup operasional dapat diefisiensikan.

\section{KESIMPULAN}

Kesimpulan yang didapatkan dalam tinjauan konseptual pada pemanfaatan teknologi e-commerce sebagai solusi inovasi dalam menjaga sustainability bisnis antara lain pertumbuhan jumlah pengguna internet yang bertumbuh pesat pada tahun 2017 menjadikan tolak ukur potensi bisnis bagi perusahaan dalam memasarkan produk melalui jalur digital untuk menjangkau pasar yang lebih luas pada tahun 2018. Dari sebanyak 143,26 juta penduduk Indonesia yang mengakses internet didapatkan 44,16\% menggunakan perangkat mobile, $0,65 \%$ yang menggunakan komputer/laptop dan dari data tersebut didapatkan bahwa perilaku pengguna saat melakukan akses terhadap situs penyedia penjualan elektronik terbanyak pada tiga jenis produk seperti pakaian jadi sebesar 45,8\%, aksesoris pakaian 10,9\%, sepatu sebesar 6,7\%.

E-commerce berperan aktif dalam menjaga tingkat permintaan terhadap barang dan jasa, memangkas biaya promosi, melebarkan pasar pada tingkatan pasar yang baru hingga dapat memangkas jalur distribusi sehingga diharapkan adanya peningkatan terhadap revenue dari organisasi tersebut. Potensi e-commerce di Indonesia sebenarnya diproyeksikan akan terus mengalami peningkatan, dari tahun 2017 yang tercatat sebesar US\$6,57 yang berarti ada pertumbuhan ekonomi sebesar 0,712\%, dan mengalami peningkatan pada tahun 2018 sebanyak US\$ 7,58 . 


\section{REFERENSI}

[1] APJII. (2017). Infografis: Penetrasi dan Perilaku Pengguna Internet Indonesia. Jakarta: APJII.

[2] Razdan, R., Dias, M. \& Sohoni, A. (2013). The Evolving Indonesian Consumer. Jakarta: McKinsey Quartely - Asia Consumer Insight Center.

[3] IPrice. Kilas Balik E-Commerce Indonesia Tahun 2017. https://iprice.co.id/trend/insights/kilas-balik-ecommerce-indonesia-2017/ diakses pada tanggal 15 April 2018 pukul 13.00 WIB

[4] Laudon, K.C. (2008). E-Commerce: Business Technology, Society 13 th. United Kingdom: Pearson.

[5] McLeod, R. (2008). Sistem Informasi Manajemen, 10 th. Jakarta : Salemba Empat.

[6] Supriyanto. (2008). Teknik Informasi \& Komunikasi SMP kelas VII. Yogyakarta: Yudhistira.

[7] IAII. Memasuki Era Internet of Things. http://iaii.or.id/read.html?id=160\&title=Indonesia Memasuki Era Internet of Things diakses pada tanggal 17 April 2017 pukul 09.30 WIB.

[8] Kroenke, D.M. \& Boyle, R.J. (2017). Experincing MIS: Global Edition 7 Th. United Kingdom: Pearson.

[9] Svenson, G. \& Wagner, B. (2011). Transformative Business Sustainability. Multilayer Model and Network of EFootprint Sources. European Business Review, Vol. 23, pp 334-352.

[10] Cory Searcy. (2011). Updating Corporate Sustainability Performance Measurement Systems. Measuring Business Excellence, Vol. 15 Issue 2, pp. 44-56.

[11] KBBI. (2005). Kamus Besar Bahasa indonesia. Jakarta: Balai Pustaka.
[12] Kuncoro, A. (2018). Ekonomi Digital, Inovasi, dan Perilaku Konsumsi. Seminar Nasional Economic Outlook 2018 Ikatan Sarjana Ekonomi Indonesia Wilayah Jawa Timur 10 Januari 2018. Jawa Timur: Ikatan Sarjana Ekonomi Indonesia.

[13] Stephen, R.P. (1994). Management. United Kingdom: Prentice Hall.

[14] Kotler, P. (2018). Principles of Marketing: Global Edition. United Kingdom: Pearson.

[15] Creswell, J.W. (2010). Research Design: Qualitative, Quantitative, and Mixed Methods Approaches, 3th. Yogyakarta.

[16] Jesson, J., Matheson, L., \& Lacey, F.M. (2011). Doing Your Literature Review: Traditional and Systematic Techniques. London: SAGE Publications.

[17] Zed, M. (2008). Metode Penelitian Kepustakaan. Jakarta: Yayasan Obor Indonesia.

[18] Kominfo. Hingga 2020 bisnis E-comemrce Indonesia diprediksi capai Rp. 1800T. https://kominfo.go.id/ content/detail/12909/hingga-2020-bisnis-e-commerceindonesia-diprediksi-capai-rp-1800-t/0/sorotan_media. diakses pada tanggal 24 Mei 2018 pukul 13.00 WIB.

[19] Cornell University, INSEAD \& WIPO. (2017). The Global Innovation Index 2017: Innovation Feeding The World.Geneva. Switzerland: Cornell University, INSEAD, and the World Intellectual.

[20] Fontana, A. (2011). Innovate We can! Manajemen Inovasi dan Penciptaan Nilai. Bekasi: Cipta Inovasi Sejahtera.

[21] Environmental Science. Three Pilars of Sustainability. https://www.environmentalscience.org/sustainability diakses pada tanggal 23 April 2018 pukul 18.30 WIB. 